\title{
Morphological and Biochemical Responses of Poincianella Pyramidalis Seedlings Subjected to Water Restriction
}

\author{
Moadir de Sousa Leite ${ }^{1}$ (1) 0000-0003-0432-0522 \\ Salvador Barros Torres ${ }^{1}$ (1) 0000-0003-0668-3327 \\ Caio César Pereira Leal ${ }^{2}$ (1) 0000-0001-7745-1836 \\ Janete Rodrigues Matias ${ }^{1}$ (i) 0000-0001-9828-9866 \\ Washington Aparecido da Luz Brito ${ }^{1}$ (1) 0000-0002-2890-2722 \\ Gutierres Silva Medeiros Aquino ${ }^{1}$ (D) 0000-0003-4492-5550
}

\begin{abstract}
Catingueira (Poincianella pyramidalis Tul. L. P. Queiroz) is an endemic species of the Caatinga, with great economic potential. Research on the development of this species under conditions of water restriction, common in the Northeastern semi-arid region, is still scarce. This study evaluated the effects of water restriction on the morphological and biochemical characteristics of catingueira seedlings subjected to water restriction. The experimental design was a randomized complete block design, with five treatments and four replicates. The treatments consisted of periods of water restriction $(0,6,12,18$ and 24 days without irrigation). The characters evaluated were shoot height, leaf diameter, number of leaves, leaf area, total dry mass, ratio between shoot height and dry mass, Dickson quality index, chlorophylls $a$ and $b$ content, total soluble sugars and free proline. Periods of water restriction longer than six days caused damage to the seedlings development, with reduced growth and quality.
\end{abstract}

Keywords: Fabaceae, water stress, catingueira, forest species, Caatinga.

\section{INTRODUCTION AND OBJECTIVES}

Several native tree species are potentially suitable for cultivation and can serve for different purposes due to their value for ornamentation, timber, food or preservation (Scalon et al., 2011). Thus, improving the production system of native species is necessary because of the increased demand for commercial production and use in the recovery of degraded areas (Nietsche et al., 2004).

Among species native to the Caatinga, catingueira [Poincianella pyramidalis (Tul.) L. P. Queiroz] is widely distributed in this biome. It has economic potential due to its rusticity and utilization for timber, reforestation, medicinal applications and mainly to its extractive property (Dantas et al., 2009).

In arid and semi-arid regions, plants are frequently exposed to water deficit, which negatively affects their growth and yield (Zhang et al., 2011). This is a frequent condition in the Northeastern semi-arid region, and the knowledge on the tolerance of plants to drought and how to exploit them is extremely important, especially regarding problems of physiological or ecological order, particularly for the recovery of areas where such type of limitation occurs (Santos et al., 2011). According to Lenhard et al. (2010), rational exploitation of the potentialities of native species in the recovery of environments with some sort of disturbance is essential to study the autoecology of the species, which is directly linked to the success or failure of the exploitation.

The physiological mechanisms of survival to drought have been widely studied in cultivated species, but little is known about the behavior and adaptive mechanisms of native species under conditions of water restriction, common in the Caatinga and semi-arid region of Brazil (Virgens et al., 2012).

Normally, plants grown in arid and semi-arid environments are exposed to long periods of water deficit in the soil and, as

\footnotetext{
${ }^{1}$ Universidade Federal Rural do Semi-Árido (Ufersa), Mossoró, RN, Brasil

${ }^{2}$ Universidade Federal do Rio Grande do Norte (UFRN), Natal, RN, Brasil
} 
a result, usually develop adaptations to tolerate this abiotic factor (Silva et al., 2009). The main adaptations for survival to water deficit include those of biochemical order related to the mechanism of osmotic adjustment of plants, such as accumulation of soluble carbohydrates (Silva et al., 2012) and free proline (Alvarenga et al., 2011), in order to maintain their water potential favorable to water absorption.

The effects of water deficit on plants are complex and there is not a standard mechanism of resistance to drought (Fernandes et al., 2015). For these authors, the variation occurs according to the intensity and duration of the water deficit and mainly to genetic traits, which are specific of each species.

Few studies report the responses of native species under water deficit conditions, such as those with Caesalpinia ferrea (Lenhard et al., 2010), Mimosa caesalpiniifolia (Moura et al., 2011), Myracrodruon urundeuva (Costa et al., 2015) and Erythrina velutina (Oliveira et al., 2016). In general, these species have strategies to deal with water deficit, an essential factor for their maintenance under adverse environmental conditions.

Given the above, this study aimed to evaluate the morphological and biochemical responses of $P$. pyramidalis seedlings subjected to different periods of water restriction.

\section{MATERIALS AND METHODS}

The experiment was conducted in the period from October to November 2017, in the seedling nursery of the Center of Agrarian Sciences at Universidade Federal Rural do SemiÁrido (Ufersa), Mossoró, RN, Brazil ( $5^{\circ} 11^{\prime} \mathrm{S}, 37^{\circ} 20^{\prime} \mathrm{W}$ and $18 \mathrm{~m}$ of altitude). During the experiment, the interior of the seedling nursery had $50 \%$ shading, average temperature of $28.6^{\circ} \mathrm{C}$ and relative humidity of $61.3 \%$.

The experimental design was a randomized complete block design (RCBD), formed by five treatments, with four replicates, in which the experimental plot was composed of 20 plants. Treatments consisted of periods of water restriction $(0,6,12,18$ and 24 days without irrigation).

Physical and chemical analyses of the soil used, which is characteristic of the region, had the following results: total sand $=0.89 \mathrm{~kg} \cdot \mathrm{kg}^{-1}$; silt $=0.07 \mathrm{~kg} \cdot \mathrm{kg}^{-1}$; clay $=0.04 \mathrm{~kg} \cdot \mathrm{kg}^{-1}$; $\mathrm{pH}$ (water) $=6.40 ; \mathrm{EC}=0.05 \mathrm{dS} \cdot \mathrm{m}^{-1} ; \mathrm{P}=4.4 ; \mathrm{K}^{+}=132.1$; $\mathrm{Na}^{+}=21.7 \mathrm{mg} \cdot \mathrm{dm}^{-3} ; \mathrm{Ca}^{2+}=2.98 ; \mathrm{Mg}^{2+}=1.40 \mathrm{cmol}_{c} \cdot \mathrm{dm}^{-3}$; $\mathrm{Cu}=0.08 ; \mathrm{Fe}=25.60 ; \mathrm{Mn}=23.57 ;$ and $\mathrm{Zn}=2.21 \mathrm{mg} . \mathrm{dm}^{-3}$.

The seeds used were collected from several trees in the state of Rio Grande do Norte and processed at the Laboratory of Seed Analysis of the Center of Agrarian Sciences of Ufersa. Direct sowing was carried out in $1.2 \mathrm{~L}$ polyethylene plastic bags. During the first 20 days after sowing (DAS), irrigation was performed twice a day, equally for all plots, and each plant received $200 \mathrm{~mL}$ of water every day. At 20 DAS, when the seedlings had two pairs of fully developed true leaves, the treatments began to be applied.

Catingueira seedlings were evaluated at 44 DAS by nondestructive and destructive measurements. Non-destructive variables were: shoot height $(\mathrm{SH})$, measured with a ruler graduated in millimeters; collar diameter (CD), measured with a digital caliper; and number of leaves (NL), determined by directly counting the number of leaves per plant. After that, destructive analysis was carried out in the seedlings, evaluating the following variables: leaf area (LA), by the corrected disc method according to Souza et al. (2012); total dry mass (TDM); and ratio between shoot height and dry mass (H/SDM).

To obtain the dry mass, four plants were randomly collected in each plot and separated into leaves, stem and roots. The material was dried in a forced air circulation oven at $65^{\circ} \mathrm{C}$ for four days, until constant weight. Weighing was performed on precision analytical scale $(0.0001 \mathrm{~g})$ and the data were expressed in g.plant ${ }^{-1}$. The results of destructive and non-destructive analyses were used to determine Dickson quality index (Dickson et al., 1960).

During the destructive analysis, the leaf material was collected, initially stored in a freezer and then used to determine biochemical variables. To determine the content of chlorophyll $a$ and $b, 0.2 \mathrm{~g}$ samples of the leaf material were placed in hermetically sealed tubes with $4.0 \mathrm{~mL}$ of $80 \%$ acetone, macerated automatically, and subjected to centrifugation and reading of the chlorophylls $a$ and $b$ content in the supernatant in a CARY $60 \mathrm{UV}$-Vis spectrophotometer.

For the contents of total soluble sugars and proline, $0.2 \mathrm{~g}$ of fresh leaf mass were weighed, placed in hermetically sealed tubes and mixed with $3 \mathrm{~mL}$ of $60 \%$ alcohol. After automatic maceration, the material was placed in water bath at $60^{\circ} \mathrm{C}$ for 20 minutes. Then the tubes were subjected to centrifugation and the supernatant was collected for quantification of the contents of total soluble sugars and proline.

The dosage of total soluble sugars was determined by the anthrone method (Yemm \& Willis, 1954), and the results were expressed in mg of glucose $/ \mathrm{g}^{-1}$ of fresh mass. Proline content was determined by applying the method proposed by Bates et al. (1973) to quantify free proline content, and the results were expressed in $\mu \mathrm{mol}$ proline $/ \mathrm{g}^{-1}$ of fresh mass.

The results were subjected to analysis of variance by F-test at 0.05 probability level, using the statistical program Sisvar (Ferreira, 2011). In case of significance, the results were subjected to regression analysis. 


\section{RESULTS AND DISCUSSION}

The analysis of variance revealed significant effect on $\mathrm{SH}$ $(p<0.05)$, TDM, CD, DQI, NL, LA and H/SDM $(p<0.01)$, indicating that the different periods of water restriction have direct influence on the initial development of Catingueira seedlings (Table 1). For these variables, the best results were obtained when they were kept under daily irrigation.

Treatments of 18 and 24 days without irrigation caused the death of 12.5 and $50 \%$ of the seedlings in the plots, respectively. According to Fernandes et al. (2015), the effects of water deficit on plants are complex and are usually affected by several factors. These factors include the genetic traits of each species, and more specifically of each individual, so that different levels of drought tolerance can be found within the same species. Thus, we observed that not even the most severe treatment, in which seedlings remained for 24 days without irrigation, was able to cause death of all plants in the plot.
For the total dry mass of $P$. pyramidalis seedlings, there was a linear reduction (Figure 1a) with the increase in the number of days without irrigation. Evaluating the effect of water deficit on the initial development of Caesalpinia ferrea seedlings, Lenhard et al. (2010) observed reduction in this variable when seedlings were cultivated in substrate moistened with a volume equivalent to $12.5 \%$ field capacity, and the best results were found in seedlings grown in substrate with moisture content close to field capacity.

Under semi-arid conditions, with low water availability and high evapotranspiration, there is a reduction in RuBisCO efficiency, which may be caused by higher resistance of the mesophyll due to stomatal closure, limiting $\mathrm{CO}_{2}$ absorption in the chloroplasts and increasing the action of RuBisCO oxygenase and, consequently, photorespiration (Scalon et al., 2011). Thus, plants kept under water stress conditions tend to accumulate less biomass and are underdeveloped, compared to those maintained under adequate water availability.

Table 1. Mean squares for TDM: total dry mass; SH: shoot height; CD: collar diameter; DQI: Dickson quality index; NL: number of leaves; LA: leaf area and H/SDM: shoot height/dry mass ratio of Poincianella pyramidalis seedlings subjected to water restriction, Mossoró, RN, 2017.

\begin{tabular}{|c|c|c|c|c|c|c|c|c|}
\hline \multirow{2}{*}{ SV } & \multirow{2}{*}{ DF } & \multicolumn{7}{|c|}{ Mean squares } \\
\hline & & TDM & SH & CD & DQI & NLF & LA & H/SDM \\
\hline PERIODS & 4 & $0.163^{\star *}$ & $6.548^{*}$ & $0.363^{\star *}$ & $0.002^{\star *}$ & $0.603^{\star *}$ & $112.356^{* *}$ & $27.600^{* *}$ \\
\hline BLOCKS & 3 & $0.039^{\text {N.S }}$ & $1.166^{\mathrm{N} . \mathrm{S}}$ & $0.058^{\star}$ & $0.0001^{*}$ & $0.034^{\mathrm{N} . \mathrm{S}}$ & $1.354^{\mathrm{N} . \mathrm{S}}$ & $29.417^{* *}$ \\
\hline RESIDUAL & 12 & 0.024 & 1.503 & 0.015 & 0.0002 & 0.097 & 4.763 & 4.802 \\
\hline CV (\%) & - & 17.06 & 8.86 & 5.87 & 16.25 & 6.27 & 6 & 10.64 \\
\hline
\end{tabular}

Probability levels: NS: not significant; ${ }^{*}$ significant at $0.05 ;{ }^{* *}$ significant at 0.01 .
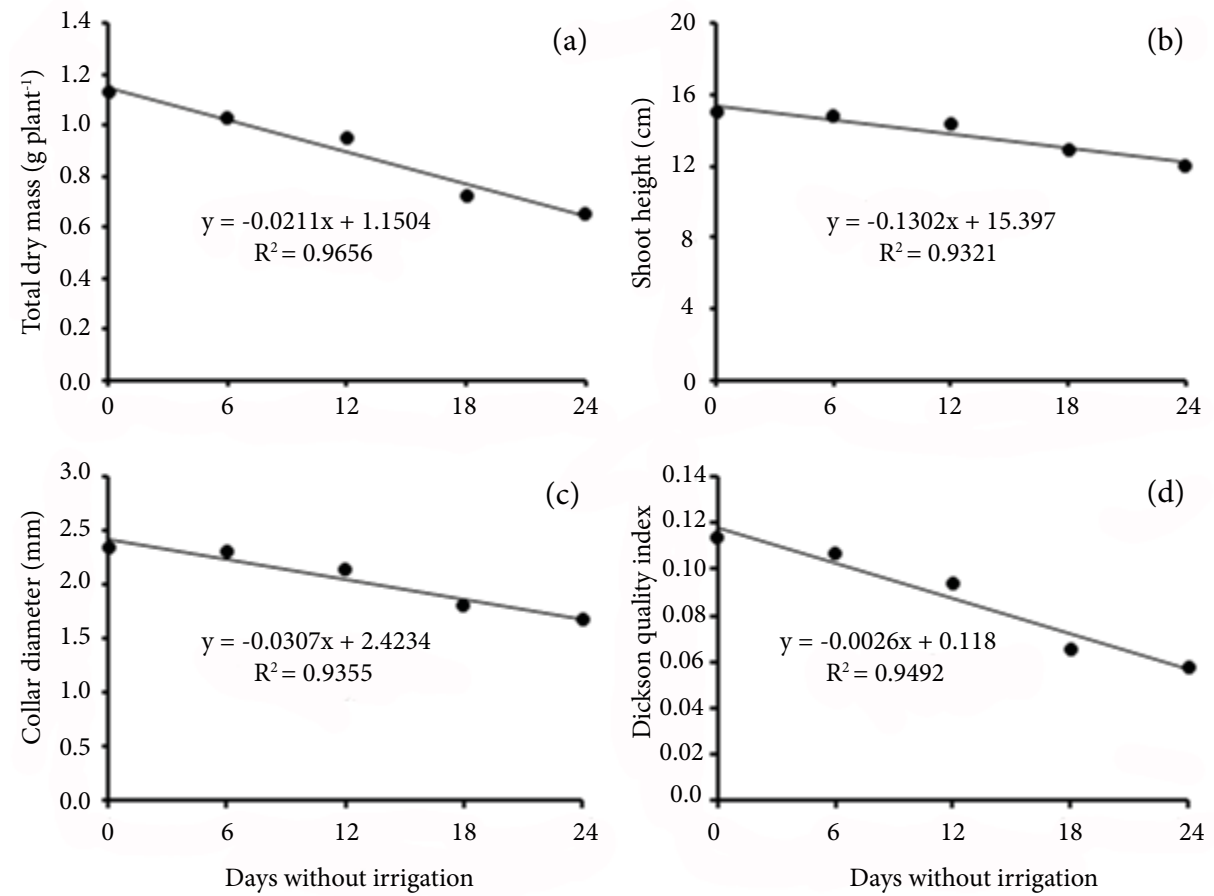

Figure 1. Total dry mass (a), shoot height (b), collar diameter (c) and Dickson quality index (d) of Poincianella pyramidalis seedlings subjected to water restriction, Mossoró, RN, 2017. 
The shoot height (Figure 1b) of catingueira seedlings decreased linearly with the increase of the water restriction period, and its highest and lowest values were obtained in the treatments of 0 and 24 days without irrigation. Similar result was observed by Scalon et al. (2011), who evaluated the effect of water stress on the initial development of Guazuma ulmifolia seedlings and observed that, in treatments with lower water availability, shoot height was 50\% lower than in the others. Oliveira et al. (2016) found reductions of $22 \%$ in the shoot height of Erythrina velutina seedlings subjected to water deficit conditions.

As observed for shoot height, collar diameter (Figure 1c) decreased with the increase in the period without irrigation. For this variable, reductions of 7, 17, 23 and 30\% were found in the treatments of $6,12,18$ and 24 days without irrigation, respectively, compared to the control treatment. According to Taiz et al. (2017), reduction of shoot height and collar diameter of seedlings may be a reflex of the reduction in cell division and expansion, caused by the lower availability of water, since it is indispensable for the occurrence of these events.

DQI is used by several authors as an important indicator of seedling quality. According to Binotto et al. (2010), this index is a balanced formula which includes relationships of morphological characters, considering the robustness and balance of biomass distribution in the seedling. For this index, the higher the value, the better the quality standard of the seedlings. Thus, the quality of $P$. pyramidalis seedlings decreased with the increase of the period without irrigation (Figure 1d).

The number of leaves (Figure 2a) gradually decreased with the increase in the number of days without irrigation. Such reduction occurred due to the fall of leaves in the treatments of greater water restriction. In deciduous plants, the fall of leaves is related to the effects of water stress (Oliveira et al., 2016), and this phenomenon is observed in several forest species, such as Poincianella pyramidalis, Mimosa caesalpiniifolia and Caesalpinia ferrea (Dombroski et al., 2011).

The leaf area of $P$. pyramidalis seedlings decreased significantly with water restriction (Figure $2 \mathrm{~b}$ ). For the treatments of 6,12,18 and 24 days without irrigation, the reductions were $6,12,19$ and $25 \%$, respectively, in comparison to the control treatment. Similar results were found by Lenhard et al. (2010) in Caesalpinia ferrea and by Scalon et al. (2011) in Guazuma ulmifolia, with lowest values of leaf area obtained in treatments with lowest water availability.

Knowledge on leaf area is extremely important for the evaluation of growth and development of a plant, because it is directly related to its photosynthetic activity (Souza et al., 2012). Reduction of leaf area is a strategy of resistance in environments with low water availability to reduce the heating of leaf tissues and plant transpiration, minimizing water loss to the environment (Scalon et al., 2011).
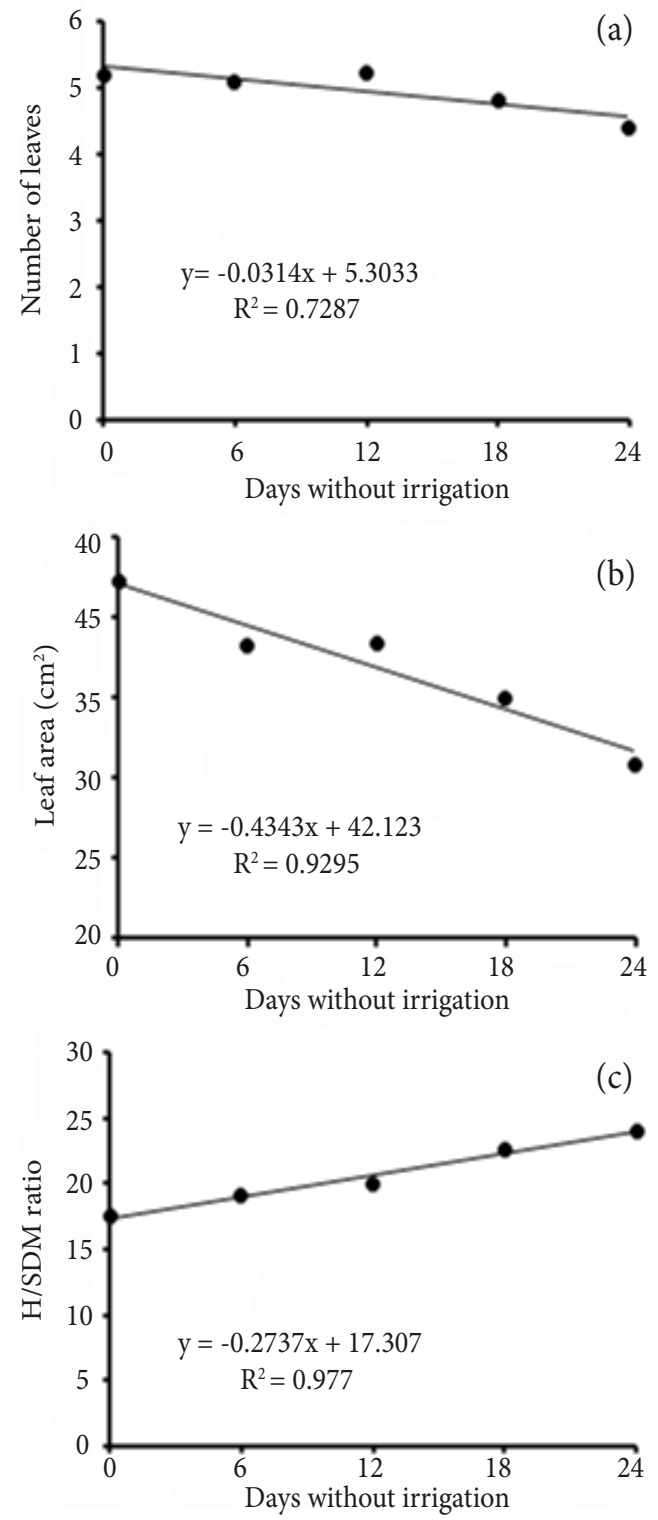

Figure 2. Number of leaves (a), leaf area (b) and shoot height/dry mass ratio (c) of Poincianella pyramidalis seedlings subjected to water restriction, Mossoró, RN, 2017.

According to Gomes et al. (2003), the result of the division of shoot height by shoot dry mass (H/SDM) is not normally used as an index to evaluate the quality of seedlings, but is very important to estimate their survival in the field. These authors also point out that the lower the index, the more lignified the seedling, leading to higher capacity of survival under unfavorable conditions. Thus, corroborating the results observed for DQI, the H/SDM ratio (Figure 2c) indicated the maximum quality of $P$. pyramidalis seedlings was obtained when they were kept under daily irrigation. Hence, their 
capacity of survival in the field was gradually reduced with the increase in the period without irrigation, which became a limiting factor for its use and for the success of these seedlings in a reforestation program.

The analysis of variance demonstrated significant effect on chlorophyll $a(p<0.05)$, chlorophyll $b$, total soluble sugars and proline $(p<0.01)$, indicating the different periods of water restriction interfere with the biochemical characteristics of P. pyramidalis seedlings (Table 2).

Table 2. Mean squares for chlorophyll $a$ (CHL a), chlorophyll $b$ (CHL b), total soluble sugars (TSS) and proline (PRLN) of Poincianella pyramidalis seedlings subjected to water restriction, Mossoró, RN, 2017.

\begin{tabular}{lccccc}
\multirow{2}{*}{ SV } & \multirow{2}{*}{ DL } & \multicolumn{4}{c}{ Mean squares } \\
\cline { 3 - 6 } & & CHL a & CHL b & TSS & PRLN \\
\hline Periods & 4 & $3.685^{\star}$ & $564.323^{* *}$ & $87.907^{* *}$ & $101.375^{* *}$ \\
\hline Blocks & 3 & $0.509^{\text {N.S }}$ & $73.532^{\text {N.S }}$ & $6.059^{\text {N.S }}$ & $1.875^{\text {N.S }}$ \\
\hline Residual & 12 & 1.048 & 37.547 & 8.114 & 4.354 \\
CV $(\%)$ & - & 2.9 & 8.99 & 16.62 & 41.66
\end{tabular}

Probability levels: NS: not significant; ${ }^{*}$ significant at 0.05 ; ${ }^{* *}$ significant at 0.01 .

The TSS content (Figure 3a) tended to increase with the increment in the period of water restriction, which was more evident for the periods of 18 and 24 days without irrigation, with increases of 48 and $67 \%$ in TSS, respectively, compared to the control treatment. According to Silva et al. (2010), under water deficit conditions, some plant species tend to increase the synthesis of soluble sugars, due to their capacity to osmotically adjust under adverse conditions of water availability.

Several studies have demonstrated accumulation of osmotically active solutes caused by water deficit (Nio et al., 2011), and the quantity and type of solute accumulated depend directly on the plant species and on water deficit duration. Costa et al. (2015) also observed TSS accumulation in Schinus terebinthifolius seedlings subjected to 12 days without irrigation, causing $41 \%$ increment compared to the control treatment.

As occurred for TSS, proline contents (Figure 3b) increased with the increment in the period of water restriction. Highest accumulation of this solute was found in the treatment of 24 days without irrigation, with proline concentration 15 times higher than that in the control treatment. To protect the plasma membrane, proline acts as antioxidant and in the maintenance of the amounts of carbon and nitrogen in plants under stress conditions (Gupta \& Huang, 2014). This mechanism is established through the accumulation, in the vacuole or cytosol, of compatible solutes such as proline, which contribute to the maintenance of water balance, being very important to increase drought tolerance (Ashraf et al., 2011).
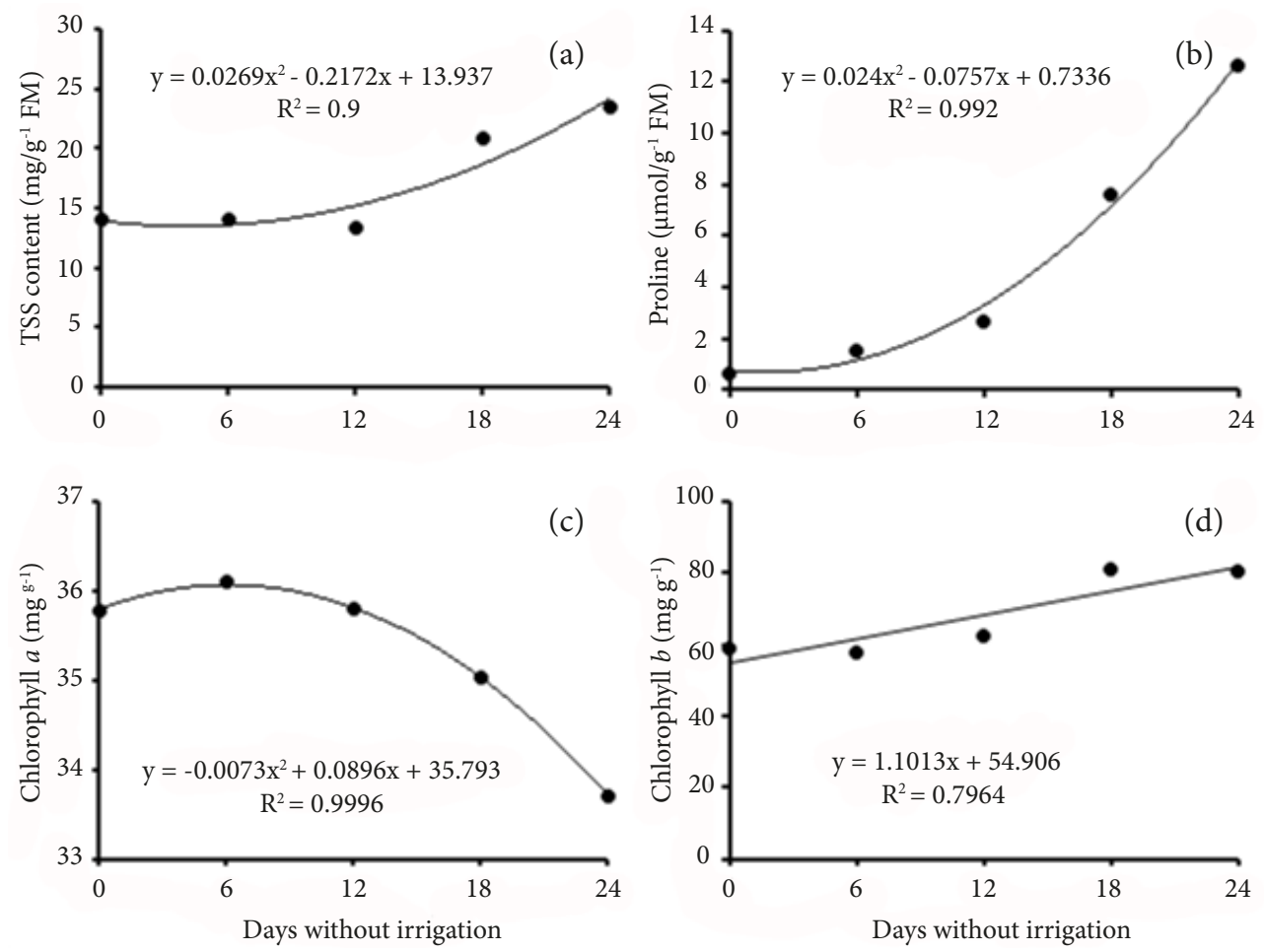

Figure 3. Contents of total soluble sugars (a), proline (b), chlorophyll $a$ (c) and chlorophyll $b$ (d) of Poincianella pyramidalis seedlings subjected to water restriction, Mossoró, RN, 2017. 
For the contents of chlorophyll $a$ (Figure 3c) and $b$ (Figure 3d), opposite responses were observed, with reduction in chlorophyll $a$ and increase in chlorophyll $b$ contents, as the periods of water restriction increased. Reduction of chlorophyll $a$ and increase in chlorophyll $b$ contents may be related to the mechanism of adaptation of this species to the stress condition, since chlorophyll $b$ is an accessory pigment which captures wavelengths of light energy that are not captured by chlorophyll $a$, thus allowing the maintenance of photosynthetic activity (Silveira et al., 2010).

\section{CONCLUSIONS}

Periods of water restriction longer than six days cause damage to the development of $P$. pyramidalis seedlings, reducing growth and quality.

P. pyramidalis is able to adapt to low water availability, expressing morphological adaptations and activation of biochemical mechanisms of resistance to water deficit.

\section{ACKNOWLEDGEMENTS}

Universidade Federal Rural do Semi-Árido (Ufersa).

\section{SUBMISSION STATUS}

Received: 27 Mar. 2018

Accepted: 24 Nov. 2018

Associate editor: João Vicente de Figueiredo Latorraca

(1) 0000-0002-5969-5199

\section{CORRESPONDENCE TO Moadir de Sousa Leite}

Universidade Federal Rural do Semi-Árido (Ufersa), Av. Francisco Mota, 572, CEP 59625-900, Mossoró, RN, Brasil

e-mail: moadir@outlook.com

\section{FINANCIAL SUPPORT}

Universidade Federal Rural do Semi-Árido (Ufersa), Grant/Award Number: 137028/2017-2.

\section{REFERENCES}

Alvarenga ICA, Queiroz GA, Honório ICG, Valadares RV, Martins ER. Prolina livre em alecrim-pimenta sob estresse hídrico antes da colheita. Revista Brasileira de Plantas Medicinais 2011; 13(spe.): 539-541. 10.1590/S1516-05722011000500006

Ashraf M, Akram NA, Al-Qurainy F, Foolad MR. Drought tolerance: roles of organic osmolytes, growth regulators, and mineral nutrients. Advances in Agronomy 2011; 111(1): 249-296. 10.1016/B978-0-12387689-8.00002-3
Bates LS, Waldren RP, Teare I. Rapid determination of free proline for water stress studies. Plant and Soil 1973; 39(1): 205-207. 10.1007/BF00018060

Binotto AF, Lúcio ADC, Lopes SJ. Correlations between growth variables and the Dickson quality index in forest seedlings. Cerne 2010; 16(4): 457-464. 10.1590/S0104-77602010000400005

Costa AS, Freire ALO, Bakke IA, Pereira FHF. Respostas fisiológicas e bioquímicas de plantas de aroeira (Myracrodruon urundeuva Allemão) ao déficit hídrico e posterior recuperação. Irriga 2015; 20(4): 705-717. 10.15809/irriga.2015v20n4p705

Dantas BF, Lopes AP, Silva FFS, Lúcio AA, Batista PF, Pires MMML, Aragão CA. Growth rates of catingueira seedlings submitted to different substrates and shading. Revista Árvore 2009; 33(3): 413423. 10.1590/S0100-67622009000300003

Dickson A, Leaf AL, Hosner JF. Quality appraisal of white spruce and white pine seedling stock in nurseries. Forest Chronicle 1960; 36(1): 10-13. 10.5558/tfc36010-1

Dombroski JLD, Praxedes SC, Freitas RMO, Pontes FM. Water relations of Caatinga trees in the dry season. South African Journal of Botany 2011; 77(2): 430-434. 10.1016/j.sajb.2010.11.001

Fernandes ET, Cairo PAR, Novaes AB. Respostas fisiológicas de clones de eucalipto cultivados em casa de vegetação sob deficiência hídrica. Ciência Rural 2015; 45(1): 29-34. 10.1590/0103-8478cr20120152

Ferreira DF. Sisvar: a computer statistical analysis system. Ciência e Agrotecnologia 2011; 35(6): 1039-1042. 10.1590/S141370542011000600001

Gomes JM, Couto L, Leite HG, Xavier A, Garcia SLR. Crescimento de mudas de Eucalyptus grandis em diferentes tamanhos de tubetes e fertilização N-P-K. Revista Árvore 2003; 27(2): 113-127. 10.1590/ S0100-67622003000200001

Gupta B, Huang B. Mechanism of salinity tolerance in plants: physiological, biochemical, and molecular characterization. International Journal of Genomics 2014; 2014: 701596. $10.1155 / 2014 / 701596$

Lenhard NR, Scalon SPQ, Novelino JO. Crescimento inicial de mudas de pau ferro (Caesalpinia ferrea Mart. ex Tul. var. leiostachya Benth.) sob diferentes regimes hídricos. Ciência e Agrotecnologia 2010; 34(4): 870-877. 10.1590/S1413-70542010000400011

Moura MR, Lima RP, Farias SGG, Alves AR, Silva RB. Efeito do estresse hídrico e do cloreto de sódio na germinação de Mimosa caesalpiniifolia Benth. Revista Verde de Agroecologia e Desenvolvimento Sustentável 2011; 6(2): 230-235.

Nietsche S, Gonçalves VD, Pereira MCT, Santos FA, Abreu SC, Mota WF. Tamanho da semente e substratos na germinação e crescimento inicial de mudas de cagaiteira. Ciência e Agrotecnologia 2004; 28(6): 1321-1325. 10.1590/S1413-70542004000600014

Nio SA, Cawthray GR, Wade LJ, Colmer TD. Pattern of solutes accumulation during leaf osmotic adjustment as related to duration of water deficit for wheat at the reproductive stage. Plant Physiology and Biochemistry 2011; 49(10): 1126-1137. 10.1016/j. plaphy.2011.05.011

Oliveira MKT, Dombroski JLD, Medeiros RCA, Medeiros AS. Desenvolvimento inicial de Erythrina velutina sob restrição hídrica. 
Pesquisa Florestal Brasileira 2016; 36(88): 481-488. 10.4336/2016. pfb.36.88.1261

Santos ARF, Silva-Mann R, Ferreira RA. Restrição hídrica em sementes de jenipapo (Genipa americana L.). Revista Árvore 2011; 35(2): 213-220. 10.1590/S0100-67622011000200006

Scalon SPQ, Mussury RM, Euzébio VLM, Kodama FM, Kissmann C. Estresse hídrico no metabolismo e crescimento inicial de mudas de mutambo (Guazuma ulmifolia Lam.). Ciência Florestal 2011; 21(4): 655-662. 10.5902/198050984510

Silva EC, Nogueira RJMC, Vale FHA, Araújo FP, Pimenta MA. Stomatal changes induced by intermittent drought in four umbu tree genotypes. Brazilian Journal of Plant Physiology 2009; 21(1): 33-42. 10.1590/S1677-04202009000100005

Silva EN, Ferreira-Silva SL, Viégas RA, Silveira JG. The role of organic and inorganic solutes in the osmotic adjustment of drought-stressed Jatropha curcas plants. Environmental and Experimental Botany 2010; 69(3): 279-285. 10.1016/j.envexpbot.2010.05.001

Silva RTL, Oliveira Neto CF, Barbosa RRN, Costa RCL, Conceição HEO. Resposta fisiológica de plantas de mamoeiro submetidas ao déficit hídrico. Nucleus 2012; 9(2): 113-120. 10.3738/1982.2278.779

Silveira JAG, Silva SLF, Silva EN, Viégas RA. Mecanismos biomoleculares envolvidos com a resistência ao estresse salino em plantas. In: Gheyi HR, Dias NS, Lacerda CF, editors. Manejo da salinidade na agricultura irrigada: estudos básicos e aplicados. Fortaleza: INCTSal; 2010. p. 181-197.

Souza MS, Alves SSV, Dombroski JLD, Freitas JDB, Aroucha EMM. Comparação de métodos de mensuração de área foliar para a cultura da melancia. Pesquisa Agropecuária Tropical 2012; 42(2): 241-245. 10.1590/S1983-40632012000200016

Taiz L, Zeiger E, Møller IM, Murphy A. Fisiologia e desenvolvimento vegetal. 6th ed. Porto Alegre: Artmed; 2017.

Virgens IO, Castro RD, Fernandez LG, Pelacani CR. Comportamento fisiológico de sementes de Myracrodruon urundeuva Fr. All. (Anacardiaceae) submetidas a fatores abióticos. Ciência Florestal 2012; 22(4): 681-692. 10.5902/198050987550

Yemm EW, Willis AJ. The estimation of carbohydrates in plants extracts by anthrone. Biochemical Journal 1954; 57(3): 508-514. 10.1042/bj0570508

Zhang M, Chen Q, Shen S. Physiological responses of two Jerusalem artichoke cultivars to drought stress induced by polyethylene glycol. Acta Physiologiae Plantarum 2011; 33(2): 313-318. 10.1007/s 11738-010-0549-z 